\title{
KEMAMPUAN KONEKSI MATEMATIS SISWA DALAM MEMECAHKAN MASALAH MATEMATIKA DITINJAU DARI JENIS KELAMIN
}

\author{
Mohamad Imron \\ Pendidikan Matematika, Fakultas Matematika dan Ilmu Pengetahuan Alam, Universitas Negeri Surabaya \\ email: mohamadimron16030174092@mhs.unesa.ac.id

\section{Masriyah} \\ Pendidikan matematika, Fakultas Matematika dan Ilmu Pengetahuan Alam, Universitas Negeri Surabaya \\ email: masriyah@unesa.ac.id
}

\begin{abstract}
Abstrak
Kemampuan koneksi matematis adalah salah satu kemampuan yang diperlukan dalam memecahkan masalah matematika. Terdapat beberapa faktor yang dapat mempengaruhi kemampuan koneksi matematis siswa, di antaranya adalah jenis kelamin. Perbedaan jenis kelamin memungkinkan adanya perbedaan kemampuan koneksi matematis setiap siswa. Penelitian ini merupakan penelitian deskriptif kualitatif yang bertujuan untuk mendeskripsikan kemampuan koneksi matematis siswa sekolah menengah pertama dalam memecahkan masalah matematika ditinjau dari jenis kelamin. Subjek penelitian terdiri dari dua siswa kelas 9 SMP dengan berjenis kelamin perempuan dan laki-laki. Hasil penelitian menunjukkan bahwa : (1) Siswa laki-laki pada tahap memahami masalah menyebutkan/menuliskan unsur-unsur yang diketahui dan yang ditanya. Pada tahap menyusun rencana siswa laki-laki menghubungkan semua konsep-konsep yang diketahuinya sehingga bisa dibuat untuk menyelesaikan masalah. Pada tahap melaksanakan rencana siswa laki-laki menuliskan langkahlangkah dalam menemukan jawaban dengan menghubungkan konsep yang satu dengan konsep yang lain. Pada tahap memeriksa kembali siswa laki-laki menjelaskan hasil kesimpulan dan menulisnya di lembar jawaban. (2) Siswa perempuan pada tahap memahami masalah, menuliskan unsur-unsur yang diketahui dan yang ditanya. Pada tahap menyusun rencana, siswa perempuan berdasarkan konsep yang sudah dikumpulkan, menghubungkan konsep yang satu dengan konsep yang lainnya. Pada tahap melaksanakan rencana, siswa perempuan menuliskan secara rinci, terstrukur, dan sistematis langkah-langkah penyelesaian dalam menghubungkan antar konsep. Pada tahap memeriksa kembali siswa perempuan telah melakukan pemeriksaan kembali terhadap hasil jawabannya serta menyimpulkan hasil pengerjaannya dan menuliskan di lembar jawaban.
\end{abstract}

Kata kunci: Koneksi Matematis, memecahkan masalah, Jenis Kelamin.

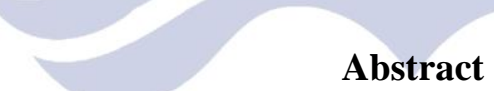

Mathematical connection ability is one of the abilities needed to solve mathematical problems. There are several factors that can affect students' mathematical connection abilities, one of them is sexs difference. It allows for differences in the mathematical connection ability of each student. This research is a qualitative descriptive study which aims to describe the mathematical connection ability of junior high school students in solving math problems in terms of sexs. The research subjects consisted of one male and one female of junior high shool students grade 9. The results showed that : (1) Male students are at the stage of understanding the problems mentioned / known and asked. At the stage of compiling a plan, male students connect all the concepts they know so that they can be made to solve problems. At the stage of carrying out the students the steps in finding answers with concepts that are connected to other concepts. In the re-examination stage, male students explain the results of the research and write them on the answer sheet. (2) Female students are at the stage of understanding the problem, which is unknown and what is being asked. At the planning stage, students based on the collected concepts, connect one concept to another. At the planning stage, female students describe detailed, structured, and systematic completion steps in a concept. In the re-examination stage, female students have reviewed the results of their answers and concluded the results of their work and reports on the answer sheets.

Keywords : Connecting Mathematical, Problem Solving, Sexs difference. 


\section{PENDAHULUAN}

Matematika adalah ilmu yang terstruktur yang saling keterkaitan antara materi yang satu dengan materi yang lainnya (Sari, 2018). Materi yang satu mungkin menjadi prasyarat untuk materi yang lain, atau konsep yang lain yang diperlukan untuk menjelaskan konsep tertentu. Pemahaman konsep matematika bagian terpenting dalam proses pembelajaran matematika (Faizah, 2019). Pentingnya pemahaman konsep matematika terlihat dalam tujuan pertama pembelajaran matematika. menurut Depdiknas (Permendiknas No. 22 tahun 2006) yaitu memahami konsep matematika yang mencakup menjelaskan keterkaitan antar konsep dan menggunakan konsep maupun algoritma secara luwes, akurat, efisien, dan tepat dalam pemecahan masalah. Berdasarkan tujuan tersebut, pembelajaran matematika diharapkan dapat membantu siswa dalam keterkaitan antar konsep dari satu materi ke materi yang lainnya. Keterkaitan antar konsep di dalam matematika lebih dikenal dengan istilah koneksi matematis.

Koneksi matematis dapat diartikan sebagai keterkaitan antar topik di dalam matematika maupun di luar matematika. Menurut Sumarmo (dalam Romli, 2016) koneksi matematis merupakan kegiatan yang meliputi : (1) mencari koneksi antara berbagai representasi konsep dan prosedur, (2) memahami koneksi antar topik matematika, (3) menggunakan matematika dalam bidang studi lain atau kehidupan sehari-hari, (4) mencari koneksi atau prosedur lain dalam representasi yang ekuivalen, dan (5) menggunakan koneksi antar topik matematika dan antar topik dengan topik lain.

Kemampuan koneksi matematis adalah kemampuan dasar yang harus dimiliki siswa. Berdasarkan National Council of Teacher of Mathematic (2000) menyatakan bahwa ada lima kemampuan dasar dalam matematika yang menjadi standar yaitu pemecahan masalah (problem solving), penalaran dan bukti (reasoning and proof), komunikasi (communication), koneksi (connection), dan representasi (reprecentation).
Kemampuan koneksi matematis siswa terbentuk melalui pengalaman dalam proses pembelajaran telah yang dilakukan. Fendrik (2019) merujuk pada National Council of Teacher of Mathematic (NCTM) menyatakan bahwa tanpa kemampuan koneksi matematis, siswa harus belajar mengetahui banyak konsep dalam matematika dan ketika siswa dapat mengoneksikan suatu konsep ke konsep yang lain, maka mereka mempunyai pandangan bahwa matematika sebagai ilmu yang utuh bukan terpisah-pisah.

Berdasarkan kutipan tersebut kemampuan koneksi matematis penting bagi siswa untuk memperluas pengetahuan dan wawasannya sehingga memandang matematika sebagai ilmu yang utuh saling berhubungan antara topik yang satu dengan topik yang lain maupun berhubungan dengan bidang selain matematika.

Terdapat standar tertentu yang perlu dikembangkan siswa melalui pembelajaran. Standar tersebut dapat menjadi ciri bahwa siswa melakukan koneksi matematis. National Council of Teacher of Mathematic (2000) menyatakan proses koneksi matematis dalam pengajaran. Menurut NCTM Intructional program from kindergarten through grade 12 should enable all students to :

a. Recognize and use connection among mathematical ideas.

b. Recognize and apply mathematics in contexts outside of mathematics

c. Understand how mathematical ideas interconnect and

build on one another to produce a coherent whole,

koneksi matematis dalam program pengajaran meliputi

a. Mengenali dan menggunakan koneksi antar gagasangagasan matematika.

b. Mengenali dan menerapkan matematika dalam konteks di luar matematika.

c. Memahami bagaimana gagasan-gagasan matematika saling keterkaitan dan membangun satu sama lain agar menghasilkan kesatuan yang utuh.

Untuk mengetahui apakah siswa menunjukkan standar koneksi matematis tersebut bisa dilihat dari 
kemampuan siswa dalam memecahkan masalah matematika. Dalam memecahkan masalah, siswa yang mempunyai kemampuan koneksi matematis lebih mudah menyelesaikan masalah yang sulit (Pradika dkk, 2019). Dengan memecahkan suatu masalah, siswa mampu membangun dan mengembangkan gagasan-gagasan dan berlatih mengintegrasikan suatu konsep, maupun suatu teorema dan keterampilan yang dipelajarinya. Selain itu dalam memecahkan masalah, siswa memeroleh pengalaman menggunakan pengetahuan serta keterampilan yang sudah dimiliki agar diterapkan pada pemecahan masalah.

Kemampuan pemecahan masalah begitu penting yang harus dimiliki setiap siswa dalam mempelajari matematika, hal ini didukung oleh Branca (dalam Sugiman dkk, 2009) menyatakan bahwa "Problem solving is the heart of mathematics" yang artinya jantungnya matematika adalah pemecahan masalah. Selanjutnya NCTM (2000) menjelaskan bahwa kemampuan pemecahan masalah adalah salah satu aspek yang penting dalam menjadikan manusia menjadi literat dalam matematika. Dari beberapa pendapat di atas dapat dinyatakan bahwa pemecahan masalah merupakan hal yang penting dalam pembelajaran matematika. Romberg (dalam Sugiman, 2009).

Untuk memecahkan masalah matematika, kita dapat menggunakan tahap-tahap pemecahan masalah menurut Polya (1973) sebagai berikut: (1) memahami masalah; (2) menyusun rencana; (3) menyelesaikan rencana serta (4) melakukan pemeriksaan kembali. Dalam memahami masalah, siswa harus dapat mencari dan menentukan apa yang diketahui dan apa yang ditanyakan. Dalam menyusun rencana, siswa mampu merancang rencana dari masalah yang ada berdasarkan apa yang diketahui dan apa yang ditanyakan pada masalah. Dalam menyelesaikan rencana, siswa harus mampu menyelesaikan masalah sesuai dengan rencana yang sudah dibuat. Pada pemeriksaan kembali hasil yang telah diperoleh, siswa harus mampu memeriksa kembali hasil yang sudah diperoleh, apakah jawabannya sudah sesuai dengan apa yang ditanyakan dalam masalah (Hasan, 2019)

Dalam menyelesaikan soal pemecahan masalah matematika tentunya kemampuan setiap siswa berbeda, khususnya ketika siswa tersebut dilihat dari jenis kelaminnya. Hasil penelitian yang dilakukan Maccoby \& Jacklyn menunjukkan bahwa permpuan dan laki-laki memiliki perbedaan kemampuan sebagai berikut: 1) perempuan memiliki kemampuan kata/verbal lebih tinggi daripada laki-laki. 2) laki-laki unggul dalam kemampuan visual spasial (penglihatan keruangan) dari perempuan. 3) laki-laki unggul dalam kemampuan matematika (dalam Amir, 2013).

Berdasarkan latar belakang di atas, peneliti tertarik untuk melaksanakan penelitian yang berjudul "Kemampuan Koneksi Matematis Siswa dalam Memecahkan Masalah Matematika ditinjau dari Jenis Kelamin”.

Penelitian ini bertujuan untuk mendeskripsikan kemampuan koneksi matematis siswa dalam memecahkan masalah matematika ditinjau dari jenis kelamin. Dalam penelitian ini difokuskan kepada siswa laki-laki dan siswa perempuan yang memiliki kemampuan matematika tinggi. Penelitian ini memberikan gambaran kemampuan koneksi matematis siswa laki-laki dan siswa perempuan dalam memecahkan masalah matematika berdasarkan langkah pemecahan masalah menurut Polya

\section{METODE}

Jenis penelitian ini termasuk penelitian deskriptif dengan pendekatan kualitatif. Penelitian ini dirancang untuk menggambarkan dan memahami suatu fenomena yang dialami dengan cara mendeskripsikan dalam bentuk kata-kata dan bahasa.

Subjek penelitian yang dipilih dalam penelitian ini ada dua siswa kelas 9 sekolah menegah pertama dengan rincian satu siswa perempuan dan satu siswa lakilaki yang memilki kemampuan matematika tinggi yang setara dan sudah dikonsultasikan kepada guru mata pelajaran perihal kemampuan tersebut. Instrumen yang digunakan dalam penelitian ini adalah lembar tes pemecahan masalah matematika dan pedoman wawancara. 
Berdasarkan tujuan penelitian, peneliti memilih dua subjek, yaitu satu perempuan dan satu laki-laki. Kedua subjek diberi lembar tes pemecahan masalah, kemudian dilakukan wawancara untuk memeroleh informasi yang lebih mendalam mengenai kemampuan koneksi matematis siswa dalam memecahkan masalah ditinjau dari jenis kelamin.

Bentuk soal merupakan permasalahan dalam kehidupan sehari-hari yang berkaitan dengan materi kesebangunan bangun datar. Pemilihan materi tersebut dengan pertimbangan bahwa kesebangunan memuat konsep-konsep matematika seperti perbandingan, pecahan serta bangun datar sehingga siswa dapat mengoneksikan pengetahuan yang mereka pelajari sebelumnya. Berikut permasalahan yang peneliti sajikan dalam tes pemecahan masalah.

"Ilvan seorang pengusaha yang mempunyai usaha dibidang konveksi. Setiap hari memproduksi baju. Bahan yang dibutuhkan untuk memproduksi baju yaitu benang dan kain. Agar bisa mengetahui biaya yang dibutuhkan untuk memproduksi dalam jumlah besar, ilvan membuat sampel baju dengan ukuran kecil terlebih dahulu. Sampel tersebut memerlukan benang sekitar $300 \mathrm{~cm}$ dan kain sebesar $0.25 \mathrm{~m}^{2}$. Panjang kain dan lebar kain yang digunakan pada sampel yaitu 1/4 dari panjang kain dan lebar kain ukuran sebenarnya. Jika harga benang sebenarnya Rp10.000,00/gulung dengan panjang 1000 meter dan harga kain Rp25.000/ $\mathrm{m}^{2}$. Berapa biaya yang dibutuhkan Ilvan untuk memproduksi 1000 baju?'

Data hasil Tes Pemecahan Masalah dianalisis dengan memfokuskan jawaban subjek berdasarkan indikator kemampuan koneksi matematis yang dikembangkan peneliti berdasarkan indikator kemampuan koneksi matematis oleh Muhamamad Romli (2016). Pada penelitian ini terdapat empat indikator yang disajikan pada tabel berikut.

Tabel 1.Indikator Kemampuan Koneksi Matematis dalam Memecahkan Masalah

\begin{tabular}{|l|l|l|}
$\begin{array}{c}\text { Tahap } \\
\text { Pemecahan } \\
\text { Masalah }\end{array}$ & \multicolumn{1}{|c|}{$\begin{array}{c}\text { Aspek } \\
\text { Kemampuan } \\
\text { Koneksi } \\
\text { Matematis }\end{array}$} & \multicolumn{1}{|c|}{$\begin{array}{c}\text { Indikator } \\
\text { kemampuan } \\
\text { Koneksi } \\
\text { Matematis }\end{array}$} \\
\hline & $\begin{array}{l}\text { Mengaplikasikan } \\
\text { ide-ide matema- }\end{array}$ & $\begin{array}{l}\text { Menemukan } \\
\text { fakta, prinsip dan } \\
\text { konsep } \\
\text { tika dalam }\end{array}$ \\
Memahami & $\begin{array}{l}\text { konteks di luar } \\
\text { matematika } \\
\text { matematika } \\
\text { konteks kehidup- }\end{array}$ & $\begin{array}{l}\text { konteks di luar } \\
\text { matematika } \\
\end{array}$ \\
& an sehari-hari) & \\
\hline
\end{tabular}

\begin{tabular}{|c|c|c|}
\hline $\begin{array}{c}\text { Tahap } \\
\text { Pemecahan } \\
\text { Masalah }\end{array}$ & $\begin{array}{c}\text { Aspek } \\
\text { Kemampuan } \\
\text { Koneksi } \\
\text { Matematis } \\
\end{array}$ & $\begin{array}{c}\text { Indikator } \\
\text { kemampuan } \\
\text { Koneksi } \\
\text { Matematis }\end{array}$ \\
\hline $\begin{array}{l}\text { Menyusun } \\
\text { Rencana }\end{array}$ & $\begin{array}{l}\text { Mampu } \\
\text { Menerapkan } \\
\text { keterkaitan antar } \\
\text { ide-ide dalam } \\
\text { matematika } \\
\text { (antar topik } \\
\text { matematika) }\end{array}$ & $\begin{array}{l}\text { Menemukan } \\
\text { keterkaitan antar } \\
\text { prinsip matema- } \\
\text { tika untuk } \\
\text { menyelesaikan } \\
\text { masalah }\end{array}$ \\
\hline $\begin{array}{l}\text { Melaksanak } \\
\text { an Rencana }\end{array}$ & $\begin{array}{l}\text { Mampu } \\
\text { Menerapkan } \\
\text { keterkaitan antar } \\
\text { ide-ide dalam } \\
\text { matematika (satu } \\
\text { topik } \\
\text { matematika) } \\
\end{array}$ & $\begin{array}{l}\text { Menggunakan } \\
\text { koneksi antara } \\
\text { fakta, prinsip } \\
\text { matematika pada } \\
\text { masalah yang } \\
\text { diselesaikan }\end{array}$ \\
\hline $\begin{array}{l}\text { Memeriksa } \\
\text { Kembali }\end{array}$ & $\begin{array}{l}\text { Mengaplikasikan } \\
\text { ide-ide dalam } \\
\text { matematika } \\
\text { maupun konteks } \\
\text { di luar } \\
\text { matematika }\end{array}$ & $\begin{array}{l}\text { Menggunakan } \\
\text { keterkaitan antar } \\
\text { konsep dengan } \\
\text { prosedur dan } \\
\text { operasi hitung } \\
\text { untuk memeriksa } \\
\text { kembali }\end{array}$ \\
\hline
\end{tabular}

Data yang diperoleh dari hasil wawancara dianalisis berdasarkan teknik analisis data kualitatif yang terdiri atas reduksi data. penyajian data, dan penarikan kesimpulan.

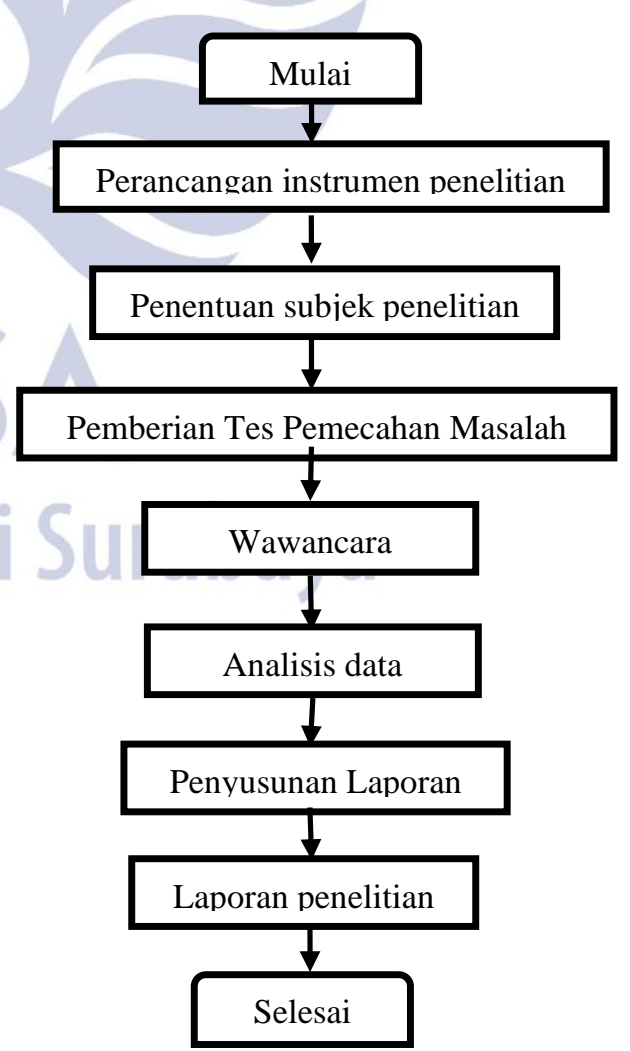

Diagram Alur Penelitian 


\section{HASIL DAN PEMBAHASAN}

Data hasil penelitian diperoleh dari hasil tes pemecahan masalah berdasarkan indikator yang telah disusun yaitu subjek mampu menemukan fakta, prinsip dan konsep matematika konteks di luar matematika, menemukan keterkaitan antar prinsip matematika untuk menyelesaikan masalah, menggunakan koneksi antara fakta, prinsip matematika pada masalah yang diselesaikan, serta menggunakan keterkaitan antar konsep dengan prosedur dan operasi hitung matematika untuk memeriksa kembali. Data tersebut kemudian dianalisis dan disajikan dalam bentuk deskripsi.

1. Kemampuan Koneksi Matematis Siswa SMP Lakilaki dalam Memecahkan Masalah Matematika

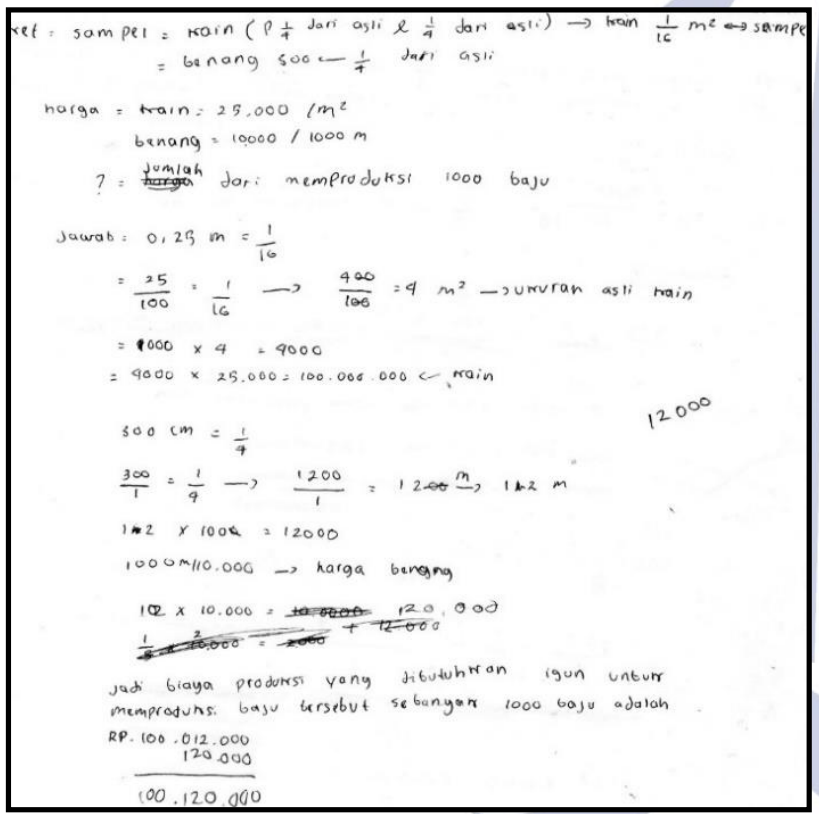

Gambar 1. Hasil Jawaban Subjek Laki-laki.

Berikut ini akan disajikan petikan wawancara terhadap subjek laki-laki mengenai kemampuan koneksi matematis pada tahap memahami masalah

Peneliti : $\quad$ Apa kamu telah membaca soal dengan cermat?

Subjek

Laki-laki : Sudah kak

Peneliti :

Ceritakan, apa saja informasi yang kamu peroleh dalam soal dengan bahasamu sendiri?

Subjek Ada pesanan baju dengan panjang dan

Laki-laki: lebar kain sampel berukuran 1/4 dari panjang dan lebar kain dengan ukuran sebenarnya. Untuk membuat sampel tersebut kain yang dibutuhkan sebesar sekitar $0.25 \mathrm{~m}^{2}$ dan benang sekitar 300 $\mathrm{cm}$. kemudian harga benangnya 10.000 untuk 1000 meter dan harga kain 25.000 per $m^{2}$. kemudian disuruh menentukan biaya produksi baju sebanyak 1000
Peneliti: $\quad$ Apa saja yang kamu ketahui dari soal?

Subjek Ada 1000 baju. Sampel baju ukuran

Laki-laki: kecil membutuhakan $0,25 \mathrm{~m}^{2}$ dan benang $300 \mathrm{~cm}$. panjang dan lebar kain sampel 1/4 dari panjang dan lebar sebenarnya. Harga benang 10.000/gulung, harga kain $25.000 / \mathrm{m}^{2}$

Peneliti : Apa yang ditanyakan dari soal?

Subjek Biaya yang diperlukan untuk Laki-laki : memproduksi 1000 baju.

Berdasarkan analisis hasil tes dan wawancara, subjek laki-laki membaca dan memahami soal dengan cermat. Kemudian menuliskan unsur-unsur yang diketahui dan yang ditanya dalam masalah matematika. Subjek menceritakan kembali apa yang ditulis, menjelaskan secara runtut dari apa yang diketahui dan apa yang ditanyakan. Subjek menjelaskan bahwa yang diminta pada soal yaitu menentukan biaya yang dibutuhkan untuk memproduksi 1000 baju. Pada tahap memahami masalah, subjek laki-laki mampu menemukan fakta, prinsip, konsep matematika dari konteks di luar matematika. Subjek menyajikan informasi (fakta) pada masalah dengan menerjemahkan permasalahan seharihari kedalam kalimat matematika. Hal ini sejalan dengan penelitian yang dilakukan Febriyanti (2016) yang menjelaskan bahwa subjek laki-laki menyebutkan atau menuliskan apa saja yang diketahui dan yang ditanyakan dalam bentuk kalimat. Dengan kemampuan koneksi matematis, memudahkan subjek untuk membuat representasi yang ekuivalen dengan masalah. Kemampuan koneksi matematis besar pengaruhnya dalam proses pemecahan masalah (Hendriana dkk, 2017). Dengan demikian pada tahap memahami masalah subjek laki-laki memenuhi indikator kemampuan koneksi matematis yaitu menemukan fakta, prinsip, konsep matematika konteks di luar matematika

Berikutnya akan disajikan petikan wawancara terhadap subjek laki-laki mengenai kemampuan koneksi matematis pada tahap menyusun rencana.

Peneliti: Kamu sudah memahami soal dengan baik, jelaskan apa saja konsep matematika yang ada dalam soal?

Subjek Ada kesebangunan, pecahan dan Laki-laki : perbandingan kak

Peneliti : $\quad$ Apakah melalui informasi yang diketahui dapat menentukan jawaban dari apa yang ditanyakan?

Subjek Iya kak

Laki-laki :

Peneliti: Apa langkah - langkah yang kamu lakukan untuk mendapatkan solusi dari penyelesaian soal tersebut? 
Subjek Mencari ukuran sebenarnya dulu, Laki-laki : $\quad$ kemudian mencari harganya. Setelah itu dijumlahkan harga benang dan harga kainnya

Peneliti: Apakah boleh langkah-langkah yang telah kamu susun dilakukan secara acak (tidak urut)?

Subjek Bisa kak

Laki-laki :

Berdasarkan analisis hasil tes dan wawancara, subjek laki-laki membuat rencana dalam pikirannya sebelum menuliskan ke dalam lembar jawaban. Dalam menyusun rencana subjek laki-laki menggunakan konsep pecahan, skala dan perbandingan dalam mengaitkan informasi dan pengetahuan yang telah dimiliki sebelumnya. Subjek menggunakan konsep skala yaitu dengan mengubah ukuran panjang dan lebar pada sampel menjadi ukuran sebenarnya kemudian mengalikan dengan harganya setelah dijumlahkan dari harga kain dan benangnya. Dalam hal ini subjek laki-laki mampu menemukan keterkaitan antar prinsip matematika untuk menyelesaikan masalah. Subjek menjelaskan tahap-tahap penyelesaian dengan benar untuk menyelesaikan masalah yaitu menggunakan prosedur yang sudah dipahami dari pertanyaan pada masalah yang akan diselesaikan. Subjek memahami bahwa prosedur pengerjaan harus berurutan serta subjek telah menggunakan koneksi antara topik pecahan dengan topik perbandingan dalam menentukan jumlah luas kain dan panjang benang yang dibutuhkan. Subjek laki-laki mampu menemukan keterkaitan hal yang ditanyakan dengan apa yang diketahui dalam masalah dengan prinsip- prinsip matematika yang telah dipahami. Dengan demikian subjek laki-laki memenuhi indikator menemukan keterkaitan antar prinsip matematika untuk menyelesaikan masalah.

Selanjutnya akan disajikan petikan wawancara terhadap subjek laki-laki mengenai kemampuan koneksi matematis pada tahap melaksanakan rencana.

Peneliti: Apakah dalam mengaitkan konsep dan prosedur yang berhubungan dengan soal kamu mengalami kesulitan?

Subjek Iya sedikit kak,

Laki-laki :

Peneliti : Coba jelaskan setiap langkah yang kamu susun tersebut secara runtut dan jelas!

Subjek Pertama yang diketahui ada sampel yang Laki-laki: panjang dan lebarnya 1/4 dari panjang dan lebar sebenarnya. Saya tentukan dulu panjang dan lebar sebenarnya hasilanya luasnya sebenarnya ketemu 4m. karena yang dibuthkan 1000 baju maka kainnya saya kalikan 1000 dan hasilnya ketemu 4000. Setelah ketemu saya kalikan dengan harganya $25.000 / \mathrm{m}^{2}$ hasilnya 100.000.000. kemudian saya mencari panjang benang sebenarnya ketemu $12 \mathrm{~m}$. karena yang dibutuhkan 1000 saya kalikan 1000 dan hasilnya 12.000. setelah ketemu saya kalikan dengan harganya yaitu 10.000/gulung dan ketemu hasilnya 120.000.000 karena 10.000/gulung dengan panjang $1000 \mathrm{~m}$ kemudian saya bagi dengan 1000 dan ketemu hasil akhirnya 120.000. terakhir saya tambahkan harga benang dan harga kainnya untuk pesananya 1000 baju tersebut hasilnya yaitu 100.120.000

Peneliti: Apakah jawaban yang kamu peroleh sudah yakin benar?

Subjek Iya kak

Laki-laki :

Berdasarkan analisis hasil tes dan wawancara, subjek laki-laki menggunakan informasi yang telah tersedia pada soal. Subjek laki-laki sedikit mengalami kesulitan dalam melaksanakan rencana namun bisa menyelesaikan dengan baik dan benar. Subjek meyakini jawaban yang diperolehnya sudah benar. Subjek mengubah pecahan decimal 0.25 menjadi pecahan biasa 25/100 atau lebih sederhananya $1 / 4$, kemudian mengubah satuan centimeter menjadi meter untuk memudahkan dalam perkalian. Ukuran sebenarnya dari kain yaitu $4 \mathrm{~m}^{2}$ dikalikan dengan harga kain. Langkah untuk menentukan benang juga sama yaitu ukuran benang sebenarnya dikalikan harganya, setelah ketemu hasilnya kemudian harga kain dan harga benang dijumlahkan. Dalam hal ini subjek mampu menggunakan koneksi antara fakta, prinsip matematika pada masalah yang akan diselesaikan. Subjek mampu menggunakan koneksi prinsip matematika satu dengan yang diketahui pada masalah dengan prinsip yang sudah dipahami sebelumnya untuk menyelesaikan masalah. Subjek mampu menggunakan keterkaitan konsep dengan prosedur dan operasi hitung matematika yang sudah dipahami untuk menyelesaikan masalah. Dengan demikian subjek laki-laki memenuhi indikator menggunakan koneksi antara fakta, prinsip matematika pada masalah yang akan diselesaikan

Kemudian, berikut ini akan disajikan petikan wawancara terhadap subjek laki-laki mengenai kemampuan koneksi matematis pada tahap memeriksa kembali.

Peneliti: Yakinkan kamu dengan konsep dan prosedur yang telah kamu digunakan?

Subjek Yakin kak

Laki-laki :

Peneliti: Sudahkah kamu memeriksa jawaban yang telah diperoleh sebelumnya?

Subjek Sudah kok kak

Laki-laki : 
Peneliti : Jelaskan kesimpulan yang kamu peroleh setelah mengerjakan masalah ini?

Subjek Jadi biaya produksi yang dibutuhkan Laki-laki: untuk membuat 1000 pesanan baju adalah 100.120.000 rupiah

Berdasarkan analisis hasil tes dan wawancara, pemeriksaan dilakukan dengan meminimalisir kesalahan perhitungan dan mengerjakan dengan hati-hati untuk menghindari kesalahan atau mengulang perhitungan. Sebelum menyerahkan lembar jawaban, Subjek laki-laki telah memeriksanya dan sudah yakin terhadap hasil yang diperoleh. Subjek laki-laki berkata: "sudah saya cek kembali kak". Subjek laki-laki tidak lupa menuliskan kesimpulan dari hasil jawabannya. Dalam hal ini subjek mampu menggunakan keterkaitan konsep dengan prosedur dan operasi hitung untuk memeriksa masalah. Subjek mampu memeriksa langkah-langkah yang sudah dikerjakan dengan mengecek ulang pengerjaan. Hal ini sejalan dengan hasil penelitian yang dilakukan oleh Febriyanti (2016) yang menjelaskan bahwa subjek lakilaki menghitung ulang jawaban yang diperoleh. Subjek juga mampu memeriksa hasil operasi hitung bilangan maupun aljabar. Dengan demikian subjek laki-laki memenuhi indikator menggunakan keterkaitan konsep dengan prosedur dan operasi hitung untuk memeriksa kembali.

Dari pembahasan di atas dikatakan bahwa subjek laki-laki memenuhi semua aspek kemampuan koneksi matematis yaitu dalam konteks kehidupan seharihari, antar topik matematika dan satu topik matematika.

2. Kemampuan Koneksi Matematis Siswa SMP Perempuan dalam Memecahkan Masalah Matematika

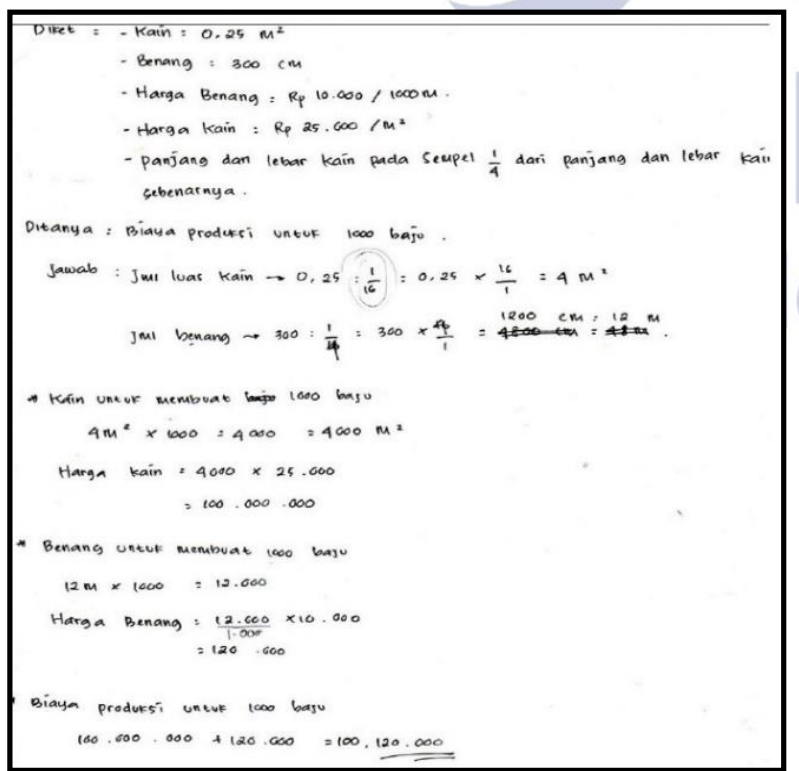

Gambar 2. Hasil Jawaban Subjek Perempuan
Berikut ini akan disajikan petikan wawancara terhadap subjek Perempuan mengenai kemampuan koneksi matematis pada tahap memahami masalah.

Peneliti : $\quad$ Apa kamu telah membaca soal dengan cermat?

Subjek

Perempuan: Sudah kak

Peneliti: $\quad$ Ceritakan, apa saja informasi yang diperoleh dalam soal dengan bahasamu sendiri?

Subjek Jadi ada usaha konveksi yang Perempuan: membuat baju dengan ukuran sampel kecil dimana panjang dan lebar kain sampel berukuran 1/4 dari panjang dan lebar kain dengan ukuran sebenarnya. Untuk membuat sampel kain yang dibutuhkan sebesar $0.25 \mathrm{~m}^{2}$ dan benang sekitar $300 \mathrm{~cm}$. kemudian harga benangnya 10.000 untuk 1000 meter dan harga kain 25.000 per $m^{2}$. terus disuruh menentukan biaya produksi baju sebanyak 1000

Peneliti : $\quad$ Apa saja yang kamu ketahui dari soal? Subjek Sampel baju ukuran kecil Perempuan: membutuhakan $0,25 \mathrm{~m}^{2}$ dan benang $300 \mathrm{~cm}$. panjang kain dan lebar kain yang digunakan pada sampel yaitu $1 / 4$ dari panjang kain dan lebar kain sebenarnya. Untuk harga benangnya 10.000/gulung, harga kain $25.000 / \mathrm{m}^{2}$. pesanan baju sebanyak 1000

Peneliti : Apa yang ditanyakn dari soal?

Subjek biaya yang diperlukan untuk Perempuan: memproduksi 1000 baju.

Berdasarkan analisis hasil tes dan wawancara, subjek perempuan membaca dan memahami soal dengan cermat kemudian menuliskan unsur-unsur yang diketahui dan yang ditanya dalam masalah matematika secara lengkap. Subjek perempuan menceritakan kembali apa yang ditulis, menjelaskan bahwa yang diminta pada soal untuk menentukan biaya yang dibutuhkan untuk memproduksi 1000 baju. Pada tahap memahami masalah subjek menyajikan informasi (fakta) pada masalah dengan menerjemahkan permasalahan sehari-hari kedalam kalimat matematika. Hal ini sejalan dengan penelitian yang dilakukan oleh Latifah (2017) yang menjelaskan bahwa subjek perempuan mampu menyebutkan yang diketahui dengan rinci dan apa yang ditanyakan pada soal. Subjek perempuan tidak mengubah kata-kata dari permasalahan yang diberikan. Subjek tidak mengubah kalimat yang terdapat pada masalah sama sekali (Febriyanti, 2016). Dengan demikian subjek perempuan memenuhi indikator kemampuan koneksi matematis yaitu menemukan fakta, prinsip, konsep matematika konteks di luar matematika 
Berikutnya akan disajikan petikan wawancara terhadap subjek perempuan mengenai kemampuan koneksi matematis pada tahap menyusun rencana.

Peneliti : $\quad$ kamu sudah memahami soal dengan baik, jelaskan apa saja konsep matematika yang ada dalam soal?

Subjek Kesebangunan kak, disitu terdapat Perempuan: perbandingan panjang dan lebar. Ada juga perbandingan, sebab ada skalaskalanya, satuannya ada yang meter dan ada yang centimeter gitu. kemudian terdapat bangun datar persegi panjang untuk kainnya kak.

Peneliti : Apakah melalui informasi yang diketahui dapat menentukan jawaban dari apa yang ditanyakan?

Subjek

Perempuan: Tidak kak

Peneliti: Apa langkah - langkah yang kamu lakukan untuk mendapatkan solusi dari penyelesaian soal tersebut?

Subjek Pertama saya menentukan jumlah luas

Perempuan: kain dan panjang sebenarnya. Kemudian menentukan luas kain untuk 1000 baju sekaligus harganya, lalu benangnya juga untuk 1000 baju sekaligus harganya. Sudah kak nanti tinggal dijumlahkan

Peneliti : Apakah boleh langkah-langkah yang telah kamu susun dilakukan secara acak (tidak urut)?

Subjek Boleh tapi ya tidak ngawur kak, kalau Perempuan: antara kain dan benang itu bebas mana yang didahulukan. Tapi kalau tahap yang cari sebenarnya kemudian ukuran 1000 baju kemudian harga menurut saya tidak bisa dibolak balik

Peneliti : $\quad$ Apakah jika dibolak-balik begitu akan menemukan hasil yang sama dek?

Subjek Iya kak, pasti sama kok.

Perempuan :

Berdasarkan analisis hasil tes dan wawancara subjek perempuan membuat rencana dalam pikirannya sebelum menuliskan kedalam lembar jawaban. Dalam menyusun rencana konsep yang digunakan subjek perempuan yaitu perbandingan panjang dan lebar perbandingan skala-skala, pecahan dan kesebangunan. Langkah yang digunakan subjek perempuan dalam menyusun rencana yaitu mengubah ukuran pada sampel menjadi ukuran sebenarnya kemudian mengalikan ukuran sebenarnya dengan masing-masing harga dari kain dan benang. Subjek perempuan meyakini rencana yang sudah disusun sesuai dengan hasil pengerjaannya dan langkahlangkah yang sudah di rencanakan bisa dibolak-balik dengan alasan bahwa hasil akhir yang akan diperoleh sama. Dalam menyusun rencana subjek perempuan mampu menemukan keterkaitan antar prinsip matematika untuk menyelesaikan masalah. Subjek mampu menjelaskan tahap-tahap penyelesaian dengan benar untuk menyelesaikan masalah menggunakan prosedur yang sudah dipahami dari pertanyaan pada masalah yang akan diselesaikan. Subjek juga mampu menentukan jumlah luas kain dan panjang benang sebenarnya menggunakan konsep pecahan dan perbandingan Dengan demikian subjek perempuan memenuhi indikator menemukan keterkaitan antar prinsip matematika untuk menyelesaikan masalah.

Selanjutnya akan disajikan petikan wawancara terhadap subjek perempuan mengenai kemampuan koneksi matematis pada tahap melaksanakan rencana.

Peneliti: Apakah dalam mengaitkan konsep dan prosedur yang berhubungan dengan soal kamu mengalami kesulitan?

Subjek

Perempuan :

Tidak kak

Peneliti: Coba jelaskan setiap langkah yang kamu susun tersebut secara runtut dan jelas!

Subjek Pertama menentukan luas kain Perempuan: sebenarnya dahulu, lah saya memerolehnya dengan cara luas kain sampel dibagi dengan 1/16, 1/16 saya dapatkan dari hasil kuadrat dari 1/4, ini karena satuannya luas sedangkan $1 / 4$ iu masih perbandingan untuk masing-msing panjang dan lebar kain sampel. Terus ketemu $4 \mathrm{~m}^{2}$. Untuk yang benang juga sama namun karena benang berkaitan dengan panjang maka cukup dibagi $1 / 4$ kak, oh ya ini tadi sedikit salah kak awalnya menggunakan 1/16 tapi setelah saya piker-pikir harusnya 1/4 dan ketemu hasilnya $12 \mathrm{~m}$. selanjutnya cari kain yang dibutuhkan untuk 1000 baju dengan mengalikan dengan $4 \mathrm{~m}^{2}$ setelah itu hasilnya dikalikan dengan harganya. Begitu juga dengan benang kak, tapi karena satuan harganya per 1000 maka setelah menemukan hasil benang 1000 baju perlu dibagi 1000 dahulu kemudian dikali dengan dengan harga benang. Lalu tinggal dijumlahkan. Ketemu deh biaya produksi untuk memproduksi 1000 baju.

Peneliti: $\quad$ Apakah jawaban yang kamu peroleh sudah yakin benar? 
Subjek

Perempuan: Sudah kak

Berdasarkan analisis hasil tes dan wawancara, subjek perempuan tidak terburu-buru dalam menyelesaikan masalah dan merasa tidak kesulitan dalam mengerjakan soal tersebut. Subjek perempuan menuliskan dan menyelesaikan masalah matematika secara runtut sesuai dengan hasil wawancara yang telah dilakukan dan meyakini hasil jawaban yang diperoleh sudah benar. Dalam melaksanakan rencana subjek perempuan mengubah pecahan desimal ke pecahan biasa dari masing-masing ukuran kain dan benang. Setelah ketemu dari harga keduanya kemudian dijumlahkan. Dalam hal ini subjek mampu menggunakan koneksi antara fakta, prinsip matematika pada masalah yang akan diselesaikan. Subjek mampu menggunakan keterkaitan konsep dengan prosedur dan operasi hitung yang sudah dipahami untuk menyelesaikan masalah. Subjek juga mampu menggunakan keterkaitan konsep dengan prosedur dan operasi hitung yang sudah dipahami untuk menyelesaikan masalah. Dengan demikian subjek perempuan memenuhi indikator menggunakan koneksi antara fakta, prinsip matematika pada masalah yang akan diselesaikan

Kemudian, berikut ini akan disajikan petikan wawancara terhadap subjek perempuan mengenai kemampuan koneksi matematis pada tahap memeriksa kembali.

Peneliti: Yakinkan kamu dengan konsep dan

Subjek Yakin kak

Perempuan :

Peneliti : $\quad$ Sudahkah kamu memeriksa jawaban yang telah diperoleh sebelumnya? Subjek Sudah kok kak

Perempuan :

Peneliti : Jelaskan kesimpulan yang kamu peroleh setelah mengerjakan masalah ini? Subjek Kesimpulannya yaitu jadi untuk Perempuan: produksi 1000 pesanan baju dibutuhkan biaya 100.120.000 rupiah

Berdasarkan analisis hasil tes dan wawancara, Subjek perempuan telah melakukan pemeriksaan kembali terhadap hasil jawabannya serta menyimpulkan hasil pengerjaannya dan menuliskan di lembar jawaban. Hal ini sejalan dengan penelitian yang dilakukan Romli (2016) yang menjelaskan bahwa subjek menuliskan kesimpulan hasil akhir jawaban. Dalam hal ini subjek mampu menggunakan keterkaitan konsep dengan prosedur dan operasi hitung matematika untuk menyelesaikan masalah. Subjek mampu memeriksa tahap-tahap yang sudah dikerjakan dengan memeriksa ulang prosedur yang digunakan. Subjek juga mampu memeriksa hasil operasi hitung dengan baik dan benar. Dengan demikian subjek perempuan memenuhi indikator menggunakan keterkaitan konsep dengan prosedur dan operasi hitung matematika untuk memeriksa kembali

Dari pembahasan di atas dikatakan bahwa subjek perempuan memenuhi semua aspek kemampuan koneksi matematis yaitu dalam konteks kehidupan sehari-hari, antar topik matematika dan satu topik matematika

\section{PENUTUP}

\section{Simpulan}

1. Siswa laki-laki pada tahap memahami masalah menyebutkan/menuliskan unsur-unsur yang diketahui dan yang ditanya serta menjelaskan dari apa yang diketahui dan apa yang ditanya dalam masalah matematika. Pada tahap menyusun rencana siswa laki-laki menggunakan semua informasi yang diperoleh dari soal kemudian siswa menghubungkan konsep-konsep yang diketahuinya sehingga bisa dibuat untuk menyelesaikan masalah. Pada tahap melaksanakan rencana siswa menuliskan langkah-langkah dalam menemukan jawaban dengan menghubungkan konsep yang satu dengan konsep yang lain yang telah direncanakan sebelumnya. Pada tahap memeriksa kembali siswa laki-laki menjelaskan hasil kesimpulan yang diperoleh dan menuliskan kesimpulan tersebut di lembar jawaban.

2. Siswa perempuan pada tahap memahami masalah, menyebutkan/menuliskan unsur-unsur yang diketahui dan yang ditanya serta menjelaskan secara runtut dari apa yang diketahui dan apa yang ditanya dalam masalah matematika. Pada tahap menyusun rencana, siswa perempuan berdasarkan konsep yang sudah dikumpulkan, menghubungkan konsep yang satu dengan konsep yang lainnya sehingga bisa dibuat sebuah rencana penyelesaian masalah. Pada tahap melaksanakan rencana, siswa perempuan menuliskan secara rinci, terstrukur, dan sistematis langkah-langkah penyelesaian dalam menghubungkan antar konsep. Pada tahap memeriksa kembali siswa perempuan telah melakukan pemeriksaan kembali terhadap hasil jawabannya serta menyimpulkan hasil pengerjaannya dan menuliskan di lembar jawaban. 


\section{Saran}

Berdasarkan hasil penelitian yang telah dilakukan, peneliti mengemukakan saran sebagai berikut.

1. Bagi seorang guru, sebaiknya merancang pembelajaran berbasis masalah kepada siswa dengan memperhatikan kemampuan koneksi matematis dalam menyelesaiakan masalah berdasarkan jenis kelamin

2. Bagi peneliti lain, sebaiknya menggunakan penelitian ini dengan tema yang sama dengan kemampuan matematis yang berbeda atau sudut peninjauan yang lain.

\section{DAFTAR PUSTAKA}

Amir, Z. 2013. "Perspektif gender dalam pembelajaran matematika”.Marwah: Jurnal Perempuan, Agama dan Jender, 12(1), 15-31.

Hardianti, A., \& Kurniasari, I. 2020. "Kemampuan Berpikir Aljabar Siswa Smp Dalam Menyelesaikan Masalah Matematika Ditinjau Dari Perbedaan Jenis Kelamin”. Jurnal Ilmiah Pendidikan Matematika Volume, 9(1).

Faizah, Ibarahim Bakoban. 2019. "Analisis pemahaman konsep dalam pembelajaran matematika". State University of Medan.

Fendrik, M. 2019. "Pengembangan kemampuan koneksi matematis dan habits of mind pada siswa". MEDIA SAHABAT CENDEKIA.

Febriyanti, R, \& Masriyah. 2016. "Profil Pemecahan Masalah Matematika Siswa dalam Menyelesaikan Soal Cerita ditinjau dari Perbedaan Jenis Kelamin”. MATHEdunesa, 5(2).

Hendriana, H., dkk. 2017. "Hard Skills dan Soft Skills Matematik Siswa” (1 ed.). (N. f. Atif, Penyunt.) Bandung: PT. Refika Aditama

Hasan, B. 2019. "The Analysis of Students' Critical Thinking Ability with Visualizer-Verbalizer Cognitive style in Mathematics". International Journal of Trends in Mathematics Education Research, 2(3), 142-148.

Latifah, M, \& Khabibah, S. 2017. Profil Pemecahan Masalah Geometri Siswa SMA Ditinjau dari Perbedaan Jenis Kelamin dan Kemampuan Spasial. MATHEdunesa, 6(3).

Mafulah, J., \& Amin, S. M. (2020). “Kemampuan Koneksi Matematis Siswa Dalam Memecahkan Masalah Matematika Ditinjau Dari Adversity Quotient”. MATHEdunesa, 9(2).

NCTM. 2000. "Principles Standards for School Mathematics". Reston: NCTM.INC.

Pradika, I. D., Amin, S. M., \& Khabibah, S. 2020. Relational thinking in problem solving mathematics based on adversity quotient and visual learning style. International Journal of
Trends in Mathematics Education Research, 2(4), 161-164.

"Peraturan Menteri Pendidikan Nasional Nomor 22 Tahun 2006 tentang Standar Isi”. Jakarta: Direktorat jenderal Manajemen Pendidikan Dasar dan Menengah.

Polya, G. 1973. "How to solve it: A new aspect of mathematical method" (1 ed.). New Jersey: Princeton University Press.

Romli, M. 2016. Profil Koneksi Matematis Siswa Perempuan SMA dengan Kemampuan Matematika Tinggi dalam Menyelesaikan Masalah Matematika. JIPMat, 1(2).

Sari, Nusi Apriana. 2018. "Analisis Kemampuan Koneksi Matematis Siswa SMP Negeri 1 Durenan Trenggalek". Undergraduate (S1) thesis, Universitas Muhammadiyah Malang

Sugiman, Kusumah. "YS, \& Sabandar.J. 2009. Pemecahan Masalah Matematik Dalam Matematika Realistik." Makalah Pendidikan Matematika Universitas Negeri Yogyakarta (2015).

Subchan, dkk. 2018. "Buku Guru Matematika untuk SMP/MTs Kelas IX Revisi 2018”. Jakarta: Kementerian Pendidikan dan Kebudayaan.

Setiawan, F. T., Suyitno, H., \& Susilo, B. E. (2017). Analysis of Mathematical Connection Ability and Mathematical Disposition Students of 11th Grade Vocational High School. Unnes Journal of Mathematics Education, 6(2), 152-162. 